Юлія Петрівна ХАРЧЕНКО

Національний університет «Чернігівська політехніка» ORCID ID: 0000-0001-6181-548X e-mail: ycharhenkoyp@gmail.com

\title{
ЗАЙНЯТІСТЬ ТА ПРОДУКТИВНІСТЬ ПРАЦІ ЯК ФУНДАМЕНТАЛЬНІ ПЕРЕДУМОВИ ІНКЛЮЗИВНОСТІ РЕГІОНАЛЬНОГО РОЗВИТКУ
}

\begin{abstract}
В статті здійснено оцінку рівня зайнятості та продуктивності праці в Україні, як базового показника оцінки рівня регіонального розвитку та акцентовано увагу на збільшенні цих показників серед громадян усіх вікових груп. Наголошено, що суттєвим викликом на регіональному рівні є обмежені можливості зайнятості, а неефективна продуктивність праці сприяє появі багатьох проблем, які гальмують розвиток територіальних громад.

Такими проблемами є зростання безробіття та соціальної напруги, пасивність мешканців громад, зниження валового виробництва і сукупноі продуктивності праці в громадах через нераціональне використання людських ресурсів. відсутність в територіальних громадах стратегічного планування розвитку, міграція за межі територіальної громади та збільшення загального демографічного, податкового навантаження на працездатне населення, адже мігрують зазвичай активні члени громади, а залишаються ті, які є пасивними та потребують захисту.
\end{abstract}

Ключові слова: регіональний розвиток, інклюзивний розвиток, зайнятість, децентралізація, територіальні громади.

Yuliia KHARCHENKO

National University "Chernihiv Polytechnic"

\section{EMPLOYMENT AND LABOR PRODUCTIVITY AS FUNDAMENTAL PRECONDITIONS FOR INCLUSIVENESS OF REGIONAL DEVELOPMENT}

The article assesses the level of employment and labor productivity in Ukraine as a basic indicator of assessing the level of regional development and focuses on increasing these indicators among citizens of all ages. It is emphasized that a significant challenge at the regional level is limited employment opportunities, and inefficient labor productivity contributes to the emergence of many problems that hinder the development of local communities.

such problems are rising unemployment and social tensions, passivity of community residents, declining gross output and total productivity in communities due to irrational use of human resources. Lack of strategic development planning in territorial communities, migration outside the territorial community and increase in the general demographic and tax burden on the able-bodied population, as active community members usually migrate, while those who are passive and need protection remain.

Keywords: regional development, inclusive development, employment, decentralization, territorial communities.

JEL Classification: A10, J21 


\section{Постановка проблеми у загальному вигляді}

та її зв'язок із важливими науковими чи практичними завданнями

Новостворена система адміністративно-територіального устрою, та власне завершення першого етапу реформи децентралізації в Україні $€$ вкрай важливим кроком для формування та реалізації принципів державної регіональної політики, яка на сьогодні $€$ одним із головних пріоритетів у порядку денному діяльності всіх гілок влади.

Зміни, які відбулися в умовах впровадження заходів 3 переформатування владних повноважень стосуються не лише регіональної складової, як об'єкта державної політики, власне зростання мобільності ресурсів, капіталів, товарів іпослуг переоцінили значення донедавна важливих чинників регіонального розвитку, серед яких: географічне розташування та територіальна близькість, а такі традиційні як наявність природних, трудових, енергетичних ресурсів чи якість наявного матеріального капіталу наразі дещо, втрачають вагомість у оцінці рівня регіонального розвитку.

Аналіз останніх досліджень і публікацій

Безперечною повагою у науковій спільноті користуються праці вітчизняних учених, які присвятили свої дослідження різним аспектам регіонального розвитку. Серед них праці О.І. Амоші, І.О. Бистрякова, Б.В.Буркинського, М.П.Бутка, В.М.Геєця, С.Й.Вовканича, А.А.Грищенка, Б.М.Данилишина, М.І.Долішнього, С.І.Дорогунцова, В.С.Загорського, В.С.Кравціва, Е.М.Лібанової, М.І.Мельник, С.І.Пирожкова, С.А.Романюка, В.Р.Сіденка, І.З.Сторонянської, М.А.Хвесика, Л.Г.Чернюк, та інших.

Виділення не вирішених раніше частин загальної проблеми

Однак, не зважаючи на ґрунтовні дослідження науковців, які сформували прикладні проблеми та концептуальні положення реформи децентралізації, вбачаємо потребу зосередити власний науковий пошук на дослідженні рівня реального стану продуктивних сил, як одного з важливих чинників інклюзивного розвитку регіонів.

Метою статті $€$ аналіз рівня реального стану продуктивних сил в Україні, як базового показника оцінки інклюзивності регіонального розвитку.

\section{Виклад основного матеріалу дослідження}

Враховуючи те, що в рамках нашого наукового дослідження, нами запропоновано, як оціночний фактор розраховувати композитний індекс інклюзивності регіонального розвитку на засадах сталості, який включає розрахунки трьох субіндексів, кожен з яких містить по 5 показників.

Зокрема, композитний рівень інклюзивності регіонального розвитку на засадах сталості (KР IPP) передбачає розрахунок:



І блоку - Рівень реального стану продуктивних сил за регіонами 3 урахуванням вагового коефіцієнту (Р Рспсв і-го) визначаємо за формулою:

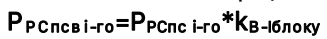

Іпс - індекс реального стану продуктивних сил

II блоку - Рівень соціальної стратифікації та спадкоємності покоління за регіонами з урахуванням вагового коефіцієнту (Рссіспв і-го) визначаємо за формулою:

$\mathrm{P}_{\text {ссіспв i-го }}=\mathrm{P}_{\text {ссісп i-го }}{ }^{*} \mathrm{k}_{\text {B- -Іблоку }}$

III блоку - Рівень соціальної стратифікації та спадкоємності покоління за регіонами з урахуванням вагового коефіцієнту ( $\mathrm{P}_{\text {Ебісрв і-го }}$ визначаємо за формулою: 


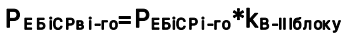

Однією з складових індексу інклюзивності $€$ визначення рівня реального стану продуктивних сил (40\% - вагомість блоку у композитному індексі). Для цього проаналізуємо показники, які мають безпосередній вплив на регіональний розвиток та, на нашу думку, зможуть об'єктивно визначити реальний стан продуктивних сил за регіонами. Серед показників: пропонуємо:

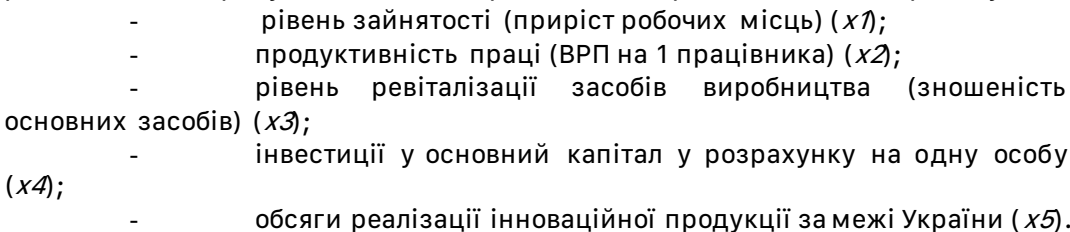
Для визначення рівня реального станупродуктивних сил за регіонами потрібно проаналізувати:

Рівень зайнятості $\left(\mathrm{V}_{\mathrm{P} 3 \mathrm{j}}=\left(\mathrm{P} 3_{\mathrm{j}}-\mathrm{P} 3_{\min }\right) /\left(\mathrm{P} 3_{\max }-\mathrm{P} 3_{\min }\right)\right)$ ВРП на 1 працівника $\left(\mathrm{V}_{\mathrm{BP} \mathrm{j}}=\left(\mathrm{BP} \Pi_{\mathrm{j}}-\mathrm{BP} \Pi_{\min }\right) /\left(\mathrm{BP} \Pi_{\max }-\mathrm{BP} \Pi_{\min }\right)\right.$, інвестиції в основний капітал у розрахунку на 1 особу ( $\mathrm{V}_{\text {Іокj }}$ $\left.=\left(10 K_{\mathrm{j}}-10 K_{\min }\right) /\left(10 K_{\max }-10 K_{\min }\right)\right)$,

- обсяги реалізації інноваційної продукції за межі України ( $\left.=\left(\mathrm{PI} \Pi_{j}-\mathrm{PI} \Pi_{\min }\right) /\left(\mathrm{PI} \Pi_{\max }-\mathrm{PI} \Pi_{\min }\right)\right)$,

інтегральний показник індексу реального стану продуктивних сил i-го року ІРСПС i-го = (VP3j +VBPПj +V3Bj +VІокj +VІокj $) /$ п.



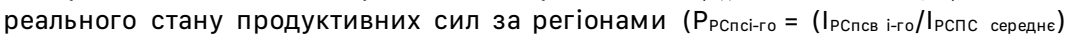
*100\%). Рівень реального стану продуктивних сил за регіонами з урахуванням вагового коефіціенту Р Рспсв і-го $=$ Рспп і-го ${ }^{*} \mathrm{k}_{\text {в-гблоку. }}$

Одним 3 п'яти показників, що характеризує ресурсний потенціал регіонів України, $€$ рівень зайнятості (у розрахунку у \% до населення відповідного віку) (табл1).

Максимальне значення показника рівень зайнятості у 2019 р. характерне Харківській області (73,3\%), а мінімальне - Волинській області $(58,7 \%)$.

Регіонами - лідерами за зазначеним показником у 2019 р. були Харківська (73,3\%), Черкаська (71,3\%), Дніпропетровська (70,5\%), Херсонська (70,5\%), Сумська (70,3\%) області, які посіли, відповідно, перші п'ять місць в рейтингу.

До групи провідних регіонів слід віднести Чернігівську (70,3\%), Київську (69,9\%), Луганську $(69,5 \%)$, Миколаївську $(69,4 \%)$ та Запорізьку $(68,5 \%)$ області, які посіли з 6-о по 10-е місця в рейтингу.

Групу регіонів зі значенням показника рівня зайнятості нижче середнього характеризували такі області: Одеська $(68,1 \%)$, Вінницька $(67,8 \%)$, Житомирська (67,8\%), Львівська $(67,0 \%)$, Полтавська (66,8\%), Хмельницька $(66,1 \%)$, Кіровоградська $(65,4 \%)$, Рівненська $(64,0 \%)$, Закарпатська $(62,9 \%)$, ІваноФранківська (62,9\%), які посідали з 11-го по 20-е місця в рейтингу.

До групи регіонів-аутсайдерів потрапили Тернопільська (62,3\%), Чернівецька (61,2\%), Донецька $(61,1 \%)$, Волинська $(58,7 \%)$ області, посідаючи 3 21-го по 24-е місця в рейтингу.

Якщо порівнювати значення досліджуваного показника у 2019 і 2010 рр., то серед областей, які суттєво покращили свої позиції в рейтингу, треба 
відзначити Сумську $(+7,2 \%)$, Чернігівську $(+6,0 \%)$ та Харківську $(+5,8 \%)$ області, а серед областей, які мали негативну динаміку в рейтингу, - Донецька $(-6,2 \%)$, Волинська $(-4,2 \%)$ та Закарпатська $(-0,7 \%)$.

Аналіз рівня зайнятості свідчить про збільшення цього показника серед громадян усіх вікових груп. Винятком $є$ особи 40-49 років, адже серед них, показник рівня зайнятості скоротився з 79,4\% до 78,7\%.

Таблиця 1

Динаміка рівня зайнятості у \%

до населення відповідного віку за 2010-2019 рр.

\begin{tabular}{|c|c|c|c|c|c|c|c|c|}
\hline \multirow[t]{2}{*}{ Області } & \multicolumn{5}{|c|}{ Роки } & \multirow{2}{*}{$\begin{array}{l}\text { Ранг, } \\
2019 \\
\text { p. }\end{array}$} & \multirow{2}{*}{$\begin{array}{c}3 \text { міна } \\
2019- \\
2017 p p .\end{array}$} & \multirow{2}{*}{$\begin{array}{c}3 \text { міна } \\
2019- \\
2010 \\
\text { рр. }\end{array}$} \\
\hline & 2010 & 2013 & 2015 & 2017 & 2019 & & & \\
\hline Україна & 65,6 & 67,4 & 64,7 & 64,5 & 67,6 & 14 & & \\
\hline АР Крим & 67,9 & 70,7 & & & & & & \\
\hline Вінницька & 63,7 & 65,4 & 65,9 & 63,9 & 67,8 & 12 & 3,9 & 4,1 \\
\hline Волинська & 62,9 & 64,7 & 60,3 & 56,1 & 58,7 & 24 & 2,6 & $-4,2$ \\
\hline Дніпропетровська & 69,4 & 71,7 & 70,9 & 67,7 & 70,5 & 3 & 2,8 & 1,1 \\
\hline Донецька & 67,3 & 69,5 & 59 & 58,2 & 61,1 & 23 & 2,9 & $-6,2$ \\
\hline Житомирська & 64,3 & 65,5 & 61,5 & 63,9 & 67,8 & 13 & 3,9 & 3,5 \\
\hline Закарпатська & 63,6 & 64,7 & 62,6 & 60,6 & 62,9 & 19 & 2,3 & $-0,7$ \\
\hline Запорізька & 67,1 & 69,5 & 65 & 64,9 & 68,5 & 10 & 3,6 & 1,4 \\
\hline Івано-Франківська & 57,6 & 60,4 & 60,3 & 60,3 & 62,9 & 20 & 2,6 & 5,3 \\
\hline Київська & 65,9 & 67,8 & 67,7 & 67,9 & 69,9 & 7 & 2,0 & 4,0 \\
\hline Кіровоградська & 65 & 66,9 & 62,5 & 62,4 & 65,4 & 17 & 3,0 & 0,4 \\
\hline Луганська & 65,1 & 66,4 & 64,1 & 62,7 & 69,5 & 8 & 6,8 & 4,4 \\
\hline Львівська & 64,1 & 65,3 & 63,9 & 64,8 & 67,0 & 14 & 2,2 & 2,9 \\
\hline Миколаївська & 66,5 & 68,8 & 67,6 & 66,2 & 69,4 & 9 & 3,2 & 2,9 \\
\hline Одеська & 65,3 & 66,8 & 65,8 & 65,3 & 68,1 & 11 & 2,8 & 2,8 \\
\hline Полтавська & 65,9 & 67,7 & 63,6 & 63,8 & 66,8 & 15 & 3,0 & 0,9 \\
\hline Рівненська & 60,8 & 62,7 & 60,4 & 57,8 & 64,0 & 18 & 6,2 & 3,2 \\
\hline Сумська & 63,1 & 65,7 & 64 & 65,6 & 70,3 & 5 & 4,7 & 7,2 \\
\hline Тернопільська & 59 & 60,4 & 58,9 & 58,4 & 62,3 & 21 & 3,9 & 3,3 \\
\hline Харківська & 67,5 & 70,3 & 69,1 & 71,0 & 73,3 & 1 & 2,3 & 5,8 \\
\hline Херсонська & 66,4 & 66,9 & 65,7 & 66,3 & 70,5 & 4 & 4,2 & 4,1 \\
\hline Хмельницька & 65,3 & 66,2 & 61,3 & 63,2 & 66,1 & 16 & 2,9 & 0,8 \\
\hline Черкаська & 67,4 & 68,7 & 66,7 & 67,5 & 71,3 & 2 & 3,8 & 3,9 \\
\hline Чернівецька & 57,5 & 59,3 & 56,3 & 58,0 & 61,2 & 22 & 3,2 & 3,7 \\
\hline Чернігівська & 64,3 & 66,2 & 64,7 & 65,6 & 70,3 & 6 & 4,7 & 6,0 \\
\hline $\begin{array}{l}\text { Мінімальне } \\
\text { значення }\end{array}$ & 57,5 & 59,3 & 56,3 & 56,1 & 58,7 & & & \\
\hline $\begin{array}{l}\text { Максимальне } \\
\text { значення }\end{array}$ & 69,4 & 71,7 & 70,9 & 71,0 & 73,3 & & & \\
\hline
\end{tabular}

Джерело: розроблено автором на підставі[2]

Серед осіб віком від 35 до 50 років (майже 80\%) спостерігається найвищий рівень зайнятості, а найнижчий - серед осіб у віці 60-70 років (14\%) та у віці 15-24 роки (31\%). Низький рівень зайнятості молоді пояснюється тим, що значна кількість осіб цього віку це учні, студенти, які навчаються тому не входять до складу робочої сили.

Аналіз обсягів та рівня зайнятості засвідчив зменшення кількості безробітних як у містах так i селах. При цьому, у міських поселеннях спостерігається збільшення кількості зайнятого населення віком 15-70 років на 143 тис. осіб (до 11,4 млн осіб), а рівень зайнятості зріс з 58,1\% до $59,1 \%$ Кількість зайнятого населення у сільській місцевості збільшилася на 74 
тис. осіб, тобто до 5,2 млн осіб, а рівень зайнятості зріс з 55,0\% до 56,2\%.

Вато зазначити, що, останнім часом на ринку праці в Україні спостерігаються суттєві гендерні особливості пов'язані з тим, що серед чоловіків чисельність зайнятого населення віком 15-70 років збільшилася на 205 тис. осіб, а от серед жінок вказаний показник збільшився лише на 12 тис. осіб. До того ж серед чоловіків рівень зайнятості становить $64,0 \%$, а серед жінок вказаний показник лише 52,9\%.

В Україні спостерігається позитивна динаміка скорочення кількості громадян зайнятих у неформальному секторі економіки. Дефініція «неформальний сектор економіки» вперше зустрічаємо у доповіді, підготовленій Міжнародною організацією праці (МОП) з питань зайнятості, у Кенії, 1972 р. Ще тоді у доповіді наголошувалось, що найбільшою проблемою зайнятості є не кількісні показники безробіття, а існування значної кількості «трудящої бідноти», представники якої змушені працювати у нелюдських умовах, продукують товари та послуги, однак обсяг діяльності їх не фіксується та не регулюється державними органами влади. Це явище в доповіді назвали «неформальний сектор економіки». Наголошено і на тому, що окремі види діяльності неформального сектора при умові мінімального сприяння та підтримці державним управлінням змогли б забезпечити зайнятість ширшому колу осіб [1].

Заслуговує уваги і той факт, що неформальний сектор зменшує певну частку безробітних або частково зайнятих працівників, тим самим пом'якшуючи соціальну напругу - створює додаткові робочі місця, сприяє підвищенню реальних доходів населення та збільшує пропозицію на ринку товарів і послуг.

Кінцевим апогеєм діяльності неформального сектора $€$ переважно товари і послуги, виготовленя і розподіл яких, не суперечить чинному законодавству. Крім того діяльність у неформальному секторі не завжди супроводжується навмисним ухиленням від сплати податків, зборів, внесків на соціальне страхування чи порушенням законодавства про працю. В науковій літературі іiї називають «економікою виживання», «економікою злиднів», «паралельною тіньовою економікою», «вимушеною економікою» тощо.

Нажаль, ще присутні випадки коли серед зайнятих громадян кожний п'ятий найманий працівник не був зареєстрований. Неформальна зайнятість була найбільш поширена у сільському, лісовому та рибному господарствах (42\%), в торгівлі, ремонті автотранспортних засобів (17\%), та у будівництві $(17 \%)$.

Питома вага зайнятих у неформальному секторі економіки була найбільш поширена у Миколаївській, Івано-Франківській, Херсонській, Рівненській, Чернівецькій областях від $34 \%$ до 49\% зайнятого населення, а найменшою - у Київській, Харківській та Полтавській областях (10\%-11\%).

Безробітне населення (за методологією МОП) у віці 15-70 років у 2019 році, у порівнянні з 2018 роком, скоротилося на 91 тис. осіб та становило 1,5 млн осіб.

Дещо зменшився вцілому і рівень безробіття (за методологією МОП) 3 $8,8 \%$ до 8,2\% робочої сили, при цьому вказане скорочення рівня безробіття відбулося в усіх регіонах. Найнижчим рівень безробіття був у Харківській області (5,0\%), м. Києві (5,8\%), Одеській та Київській областях (відповідно, по 5,9\%), а найвищим - у Луганській (13,7\%), Донецькій (13,6\%), Кіровоградській (11,0\%), Полтавській та Волинській областях (відповідно, по 10,6\%). 
Варто наголосити, що скорочення рівня безробіття спостерігалося серед громадян віком від 15 до 39 років, однак серед осіб віком 40-49 років рівень безробіття зріс з 7,7\% до 8,4\%, серед осіб 50-59 років - 3 7,4\% до $8,0 \%$. Серед осіб у віці 30-34 роки (7,3\%) найнижчий рівень безробіття, в той же час серед молоді до 25 років цей показник становив $15,4 \%$ робочої сили відповідного віку (майже удвічі вище, ніж серед усього населення) .

Рівень зайнятості населення України у 2019 році $(67,6 \%)$ у порівнянні 32010 роком (65,6\%) зростає, спад спостерігався у 2015 (64,7\%), у 2017 (64,5\%).

Регіональна диференціація рівня економічної активності обумовлюється особливостями статево-вікової структури населення, загальною ситуацією на ринках праці, традиційно-культурною специфікою регіонів.

Таблиця 2

Динаміка рівня безробіття з 2000 по 2020

\begin{tabular}{|c|c|c|c|c|c|c|}
\hline \multicolumn{7}{|c|}{$\begin{array}{c}\text { Рівень без робіття в Україні з } 2000 \text { по } 2020 \text { рр. } \\
\text { (кільк. населення в тис.) }\end{array}$} \\
\hline Роки & $\begin{array}{l}\text { Всього } \\
\text { населення }\end{array}$ & $\begin{array}{c}\text { Економічно } \\
\text { а ктивне } \\
\text { на селення }\end{array}$ & $\begin{array}{c}\text { Зайняте } \\
\text { населення }\end{array}$ & $\begin{array}{l}\text { Безробітне } \\
\text { на селення }\end{array}$ & $\begin{array}{c}\text { Рівень } \\
\text { безробіття }\end{array}$ & $\begin{array}{l}\text { Зареєстрованих } \\
\text { бе зробітних }\end{array}$ \\
\hline 2000 & 48923,2 & 21150,7 & 18520,7 & 2630,0 & $12,4 \%$ & 1178,7 \\
\hline 2001 & 48457,1 & 20893,6 & 18453,3 & 2440,3 & $11,7 \%$ & 1063,2 \\
\hline 2002 & 48003,5 & 20669,5 & 18540,9 & 2128,6 & $10,3 \%$ & 1028,1 \\
\hline 2003 & 47622,4 & 20618,1 & 18624,1 & 1994,0 & $9,7 \%$ & 1024,2 \\
\hline 2004 & 47280,8 & 20582,5 & 18694,3 & 1888,2 & $9,2 \%$ & 975,5 \\
\hline 2005 & 46929,5 & 20481,7 & 18886,5 & 1595,2 & $7,8 \%$ & 891,9 \\
\hline 2006 & 46646,0 & 20545,9 & 19032,2 & 1513,7 & $7,4 \%$ & 784,5 \\
\hline 2007 & 46372,7 & 20606,2 & 19189,5 & 1416,7 & $6,9 \%$ & 673,1 \\
\hline 2008 & 46143,7 & 20675,7 & 19251,7 & 1424,0 & $6,9 \%$ & 596,0 \\
\hline 2009 & 45962,9 & 20321,6 & 18365,0 & 1956,6 & $9,6 \%$ & 693,1 \\
\hline 2010 & 45778,5 & 20220,7 & 18436,5 & 1784,2 & $8,8 \%$ & 452,1 \\
\hline 2011 & 45633,6 & 20247,9 & 18516,2 & 1731,7 & $8,6 \%$ & 505,3 \\
\hline 2012 & 45553,0 & 20393,5 & 18736,9 & 1656,6 & $8,1 \%$ & 467,7 \\
\hline 2013 & 45426,2 & 20478,2 & 18901,8 & 1576,4 & $7,7 \%$ & 487,6 \\
\hline 2014 & 42928,9 & 19035,2 & 17188,1 & 1847,1 & $9,7 \%$ & 458,6 \\
\hline 2015 & 42760,5 & 17396,0 & 15742,0 & 1654,0 & $9,5 \%$ & 461,1 \\
\hline 2016 & 42584,5 & 17303,6 & 15626,1 & 1677,5 & $9,7 \%$ & 407,2 \\
\hline 2017 & 42386,4 & 17193,2 & 15495,9 & 1697,3 & $9,9 \%$ & 352,5 \\
\hline 2018 & 42153,2 & 17296,2 & 15718,6 & 1577,6 & $9,1 \%$ & 341,7 \\
\hline 2019 & 41902,4 & 17381,8 & 15894,9 & 1486,9 & $8,6 \%$ & 338,2 \\
\hline 2020 & 41588,4 & 16917,8 & 15244,5 & 1673,3 & $9,9 \%$ & 459,2 \\
\hline
\end{tabular}

з 2014 р. - без урахування окупованих територій (Криму, Севастополя, частини Донбасу) Джерело: розробленоавтором на підставі[3]

Одним із найважливіших питомих показників, що характеризує зміни обсягів суспільного виробництва в регіональному розрізі, $\epsilon$ продуктивність праці у розрахунку тис. грн. на 1 особу.

У табл. 2 наведено дані, що характеризують зміни зазначено показника за період 2010-2019 рр.

У 2019 р. регіонами - лідерами за показником продуктивність праці у розрахунку тис. грн. на 1 особу були Полтавська (134449 грн.), Київська (123267 грн.), Дніпропетровська (122379 грн.), Харківська (92864 грн.) та Запорізька (91498грн.) області, які посіли перші п'ять місць у рейтингу. 
ISSN 2786-5339

Динаміка продуктивності праці

у роз рахунку тис. грн. на 1 особу за 2010-2019 рр.

\begin{tabular}{|c|c|c|c|c|c|c|c|c|}
\hline \multirow[t]{2}{*}{ Регіони } & \multicolumn{5}{|c|}{$\begin{array}{c}\text { Продуктивність праці } \\
\text { (ВРП на } 1 \text { працівника) } \\
\text { тис. грн/особу }\end{array}$} & \multirow[t]{2}{*}{$\begin{array}{c}\text { Ранг, } \\
2019 \\
\text { p. }\end{array}$} & \multirow[t]{2}{*}{$\begin{array}{c}3 \text { міна } \\
2019- \\
2017 p p .\end{array}$} & \multirow{2}{*}{$\begin{array}{c}3 \text { міна } \\
2019- \\
2010 \\
\text { pp. }\end{array}$} \\
\hline & 2010 & 2013 & 2015 & 2017 & 2019 & & & \\
\hline Україна & 23600 & 33473 & 46413 & 70233 & 94661 & & & \\
\hline АР Крим & 16507 & 23595 & $\ldots$ & ... & & & & \\
\hline Вінницька & 14332 & 22303 & 37270 & 58384 & 83175 & 8 & 24791 & 68843 \\
\hline Волинська & 13916 & 19817 & 30387 & 49987 & 73215 & 13 & 23228 & 59299 \\
\hline Дніпропетровська & 34709 & 46333 & 65897 & 97137 & 122379 & 3 & 25242 & 87670 \\
\hline Донецька & 28986 & 37830 & 26864 & 39411 & 49422 & 21 & 10011 & 20436 \\
\hline Житомирська & 14616 & 20286 & 30698 & 49737 & 70247 & 15 & 20510 & 55631 \\
\hline Закарпатська & 12278 & 17044 & 22989 & 34202 & 48861 & 22 & 14659 & 36583 \\
\hline Запорізька & 23657 & 30526 & 50609 & 75306 & 91498 & 5 & 16192 & 67841 \\
\hline Івано-Франківська & 14814 & 24022 & 33170 & 46312 & 63254 & 17 & 16942 & 48440 \\
\hline Київська & 26140 & 39988 & 60109 & 90027 & 123267 & 2 & 33240 & 97127 \\
\hline Кіровоградська & 15533 & 25533 & 39356 & 55183 & 77816 & 12 & 22633 & 62283 \\
\hline Луганська & 19788 & 24514 & 10778 & 13883 & 18798 & 24 & 4915 & -990 \\
\hline Львівська & 16353 & 24937 & 37338 & 58221 & 85198 & 7 & 26977 & 68845 \\
\hline Миколаївська & 20276 & 27355 & 41501 & 60549 & 82149 & 10 & 21600 & 61873 \\
\hline Одеська & 22544 & 29118 & 41682 & 62701 & 82903 & 9 & 20202 & 60359 \\
\hline Полтавська & 29652 & 39962 & 66390 & 106248 & 134449 & 1 & 28201 & 104797 \\
\hline Рівненська & 13785 & 19003 & 30350 & 42038 & 58332 & 19 & 16294 & 44547 \\
\hline Сумська & 15711 & 23517 & 37170 & 51419 & 70576 & 14 & 19157 & 54865 \\
\hline Тернопільська & 11713 & 16819 & 24963 & 38593 & 54833 & 20 & 16240 & 43120 \\
\hline Харківська & 23639 & 31128 & 45816 & 69489 & 92864 & 4 & 23375 & 69225 \\
\hline Херсонська & 14346 & 19311 & 30246 & 45532 & 59987 & 18 & 14455 & 45641 \\
\hline Хмельницька & 13602 & 20165 & 31660 & 49916 & 65916 & 16 & 16000 & 52314 \\
\hline Черкаська & 17325 & 26168 & 40759 & 59697 & 86319 & 6 & 26622 & 68994 \\
\hline Чернівецька & 10939 & 15154 & 20338 & 31509 & 46136 & 23 & 14627 & 35197 \\
\hline Чернігівська & 15406 & 22603 & 35196 & 55198 & 78118 & 11 & 22920 & 62712 \\
\hline
\end{tabular}

Джерело: розроблено автором на підставі[2]

До групи регіонів, що наближаються до середнього значення показника продуктивності праці в розрахунку на 1 особу по Україні (94661 грн.), увійшли Черкаська (86319 грн.), Львівська (85198грн.), Вінницька (83175 грн), Одеська (82903 грн.) та Миколаївська (82149 грн.) області, які посіли з 6 по 10 місце в рейтингу.

Регіонами, які мали значення зазначеного показника значно нижче середнього по Україні, були: Чернігівська (78118грн.), Кіровоградська (77816 грн.), Волинська (73215 грн.), Сумська (70576 грн.), Житомирська (70247 грн.), Хмельницька (65916 грн.), Івано-Франківська (63254 грн.), Херсонська (59987 грн.), Рівненська (58332 грн.) та Тернопільська (54833 грн.) області, які посідали з 11 по 20 місце в рейтингу.

Регіонами - аутсайдерами було визначено тимчасово окуповані території Донецької (49422 грн.) та Луганської (18798 грн.) областей, а також Закарпатська (48861 грн.) та Чернівецька (46136 грн.) області.

\section{Висновки з даного дослідження}

\section{і перспективи подальших розвідок у даному напрямі}

Проведене дослідження довело, що зайнятість населення та продуктивність праці в Україні останніми роками значно змінюється, однак вцілому загальний їх рівень залишається досить високим. 
Наразі спостерігаємо істотні структурні зрушення зайнятості, серед яких гнучкіший ринок праці, скорочення масштабів зайнятості у нелегальній сфері економіки, значного поширюється неформальна зайнятість, оскільки є найбільш доступною і не ставить високих професійно-кваліфікаційних вимог до працівників, серед яких діяльність в домогосподарствах та ін.; через пандемію значні контингенти трудових мігрантів, які здійснювали виїзди на більш тривалий термін на роботу в іншу місцевість або за кордон змушені залишитись в Україні.

Від ситуації на регіональному ринку праці суттєво залежним є рівень економічного розвитку регіону, його стабільність, ступінь довіри населення до керівництва громад, розвиток активного громадянського суспільства, наявність соціального діалогу, екологічна ситуація, формування зон розселення, залежно від розміщення підприємницьких об'єктів (насамперед, промислових), на яких концентрується значна кількість економічно активного населення, тобто інклюзивність регіонального розвитку на засадах сталості.

Аналітичні дослідження оголили основні проблеми розвитку зайнятості в територіальних громадах, і якщо порівнювати результати, то ці проблеми будуть спільними для всіх областей України. Зокрема такими проблемами будуть [5]:

1. Несприятливі умови працевлаштування і розвитку трудового потенціалу, що підтверджує низька стратегічна орієнтованість ОТГ у питаннях планування і прогнозування їхнього розвитку (серед областей Центральної України 65,4\% ОТГ має загальну стратегію та 46,8\% - програму/план зайнятості, для західних областей 47,1\% ОТГ має загальну стратегію, 11,4\% - програму/план зайнятості)

2. Низький рівень конкурентоспроможності місцевих роботодавців та неефективна зайнятість, тобто неофіційна зайнятість та тіньова.

3. Міграція населення з територіальних громад за внутрішнім і зовнішнім векторами.

4. Відсутність якісного обліку населення (серед центральних областей опис людських ресурсів наявний лише у 40,3\% ОТГ, для західних ОТГ - 32,9\%).

Суттєвим викликом на регіональному рівні є обмежені можливості зайнятості, а неефективна зайнятість населення сприяє появі багатьох проблем які гальмують розвиток територіальних громад.

Такими проблемами є:

- зростання безробіття та соціальної напруги внаслідок зниження економічної активності мешканців громад, у тому числі через пандемію COVID19 та обмеження діяльності, залежно від рівня епідемічної небезпеки;

- пасивність мешканців громад, небажання участі у вирішенні питань громади;

- зниження валового виробництва і сукупної продуктивності праці в громадах через нераціональне використання людських ресурсів;

- відсутність в територіальних громадах стратегічного планування розвитку пасивність в долученні до проектів розвитку;

- міграція за межі територіальної громади та збільшення загального демографічного, податкового навантаження на працездатне населення, адже мігрують зазвичай активні члени громади, а залишаються ті, які є пасивними та потребують захисту.

Варто наголосити, що наслідком демографічних втрат територіальних громад є послаблення можливостей капіталізації людського потенціалу як 
передумови зростання ринкової вартості людських ресурсів та, відповідно, перспектив економічного зростання громад [6, с. 48].

Крім того, демографічна ситуація, що складається в громадах значною мірою визначає кон'юнктуру ринків праці та рівень їх збалансованості. А тому, зменшення кількості економічно активного населення та наявність інших несприятливих чинників сприяє не лише посиленню демографічного навантаженню, а приводить до проблеми відтворення людських ресурсів, позбавляє перспективи зменшення трудової міграції, створення нових робочих місць.

Керуючись досвідом постсоціалістичних країн ЄС інституціональними передумовами для використання економічного потенціалу у нашій державі мали б стати мотивація до створення нових робочих місць у всіх сферах господарювання, реалізація програми імпортозаміщення та активізації функціонування внутрішнього ринку, формування інвестиційної привабливості окремих територій та налагодження ефективних міжрегіональних зв'язків [7].

\section{Література}

1. Офіційна веб-сторінка Міжнародної організації праці [Електронний ресурс]. - Режим доступу: ww.ilo.org

2. Офіційна веб-сторінка Державної служби статистики [Електронний ресурс]. - Режим доступу: http://www.ukrstat.gov.ua/

3. Офіційна веб-сторінка Державного центру зайнятості [Електронний ресурс]. - Режим доступу: https://www.dcz.gov.ua/analitics/67

4. Мінфін [Електронний ресурс]. - Режим доступу : https://index.minfin.com.ua/ua/labour/unemploy/

5. М. М. Біль, О. О. Левицька. Потенціал активізації зайнятості населення об'єднаних територіальних громад західних та центральних областей України http://www.economy.nayka.com.ua/?op=1\&z=7518

6. Дерій Ж. В., Маргасова В. Г. Модель управління процесом капіталізації людського потенціалу на регіональному рівні. Проблеми і перспективи економіки та управління. 2015. № 4. С. 46-54.

7. Інституціональні засади модернізації продуктивних сил регіонів України в умовах децентралізації управління [Текст] / М. П. Бутко, Ю. П. Харченко // Економіка України. -2020. - № 8. - С. 58-75.

\section{References}

1. Official web-page of the International Labor Organization [Electronic resource]. - Access mode: ww.ilo.org

2. Official web-page of the State Statistics Service [Electronic resource]. - Access mode: http://www.ukrstat.gov.ua/

3. Official web-page of the State Employment Center [Electronic resource]. - Access mode: https://www.dcz.gov.ua/analitics/67

4. Ministry of Finance [Electronic resource]. - Access mode: https://index.minfin.com.ua/ua/labour/unemploy/

5. MM Bil, OO Levitska POTENTIAL OF ACTIVATION OF EMPLOYMENT OF THE POPULATION OF THE UNITED TERRITORIAL COMMUNITIES OF THE WESTERN AND CENTRAL REGIONS OF UKRAINE http://www.econom.

6. Deriy Zh. V., Margasova VG Model of management of the process of capitalization of human potential at the regional level. Problems and prospects of economics and management. 2015. № 4. pp. 46-54.

7. Institutional principles of modernization of productive forces of regions of Ukraine in the conditions of decentralization of management [Text] / MP Butko, Yu. P. Kharchenko // Economy of Ukraine. 2020. - № 8. - P. 58-75.

Стаття надійшла до редакції 01.10.2021 